\title{
HUMAN TOXOCARIASIS: CONTRIBUTION BY BRAZILIAN RESEARCHERS
}

\author{
Pedro Paulo CHIEFfI(1,2), Sérgio Vieira dos SANTOS(1), Maisa Leite de QUEIROZ(1,2) \& Susana A. Zevallos LESCANO(1)
}

\begin{abstract}
SUMMARY
In the present paper the main aspects of the natural history of human infection by Toxocara larvae that occasionally result in the occurrence of visceral and/or ocular larva migrans syndrome were reviewed. The contribution by Brazilian researchers was emphasized, especially the staff of the Tropical Medicine Institute of São Paulo (IMT).
\end{abstract}

KEYWORDS: Toxocara; Toxocara canis; Visceral and ocular larva migrans.

\section{INTRODUCTION}

Human infection by larvae of Toxocara is currently considered an important zoonosis and the principal cause of visceral larva migrans and other related syndromes.

More than 50 years ago, while analyzing liver biopsies taken from three children suffering from hepatomegaly, respiratory symptoms, anemia and very elevated eosinophilia, BEAVER et al. ${ }^{13,15}$ observed Toxocara canis larvae within eosinophilic granulomata. Thus, they described a new syndrome called visceral larva migrans (VLM), caused by the erratic and prolonged migration principally by Toxocara and, occasionally, by other nematode larvae, in unusual hosts, denominated paratenic hosts, in whose tissues and organs the larvae remain alive and viable for long periods. In 1956, NICHOLS ${ }^{76}$ identified Toxocara canis larvae in enucleated eye sections from certain patients supposedly presenting retinoblastoma, describing the clinical and anatomopathological features of ocular larva migrans (OLM). Approximately three decades later, other aspects of the syndrome known as covert toxocariasis (CT), characterized by abdominal pain, coughing, headache and normal or mildly elevated eosinophilia, with the presence of serum anti-Toxocara antibodies, were described ${ }^{12,98}$.

The great majority of larvae identified in human cases of VLM or OLM were classified as belonging to T. canis, although other species of the genus Toxocara have sporadically been detected in biopsies as etiological agents, as well as other nematode species, such as Gnathostoma spinigerum and Ancylostoma caninum $^{84}$. It is fairly common in the medical literature to consider the various forms of visceral or ocular larva migrans as human toxocariasis infection.

Although the majority of humans infected by Toxocara larvae present an asymptomatic course, some symptomatic patients can present important disease. SMITH et al..$^{96}$ recently reviewed the principal symptoms and signs present in the three clinical types of human toxocariasis as follow: VLM: fever, pallor, malaise, irritability, weight loss, cutaneous rash, hepatomegaly, respiratory and nervous disturbs, myocarditis, hypergammaglobulinemia, leukocytosis and eosinophilia, elevated anti-A and anti-B isohemagglutinins;

OLM: visual loss, strabismus, retinal granuloma and detachment, endophthalmitis, chorioretinitis, uveitis;

CT: coughing, abdominal pain, headache, sleep and behavioral disturbances.

The aim of this paper is to review the principal aspects of the natural history of Toxocara human infection, emphasizing the contribution of Brazilian researchers, especially those working at the Tropical Medicine Institute of São Paulo.

Toxocara canis infection in dogs: Dogs and other canid species are the natural hosts of Toxocara canis and can be infected by several mechanisms: ingestion of Toxocara canis embryonated eggs, transplacentary or transmammary transmission of third stage larvae, predation of infected paratenic hosts (principally rodents) and, finally, by ingestion of Toxocara canis young adults sometimes eliminated by infected pets.

The type of larval migration (tracheal or somatic) presented by infected dogs depends principally on the animal's age. Young dogs, less than five to six months old, usually present tracheal larval migration, resulting in the presence of intestinal adult worms, responsible for fecal egg delivering; older dogs, previously infected by transplacentary or transmammary mechanisms, present somatic larval migration, resulting in encysted third stage larvae in their tissues. In this case pregnant females may transmit Toxocara larvae to their progeny ${ }^{80}$.

As human toxocariasis is a consequence of soil contamination by Toxocara canis eggs, the frequency of dog infection by this ascarid should be considered a good index for evaluating human risk of infection. Several

Work published as part of the celebration of the $50^{\text {th }}$ anniversary of the São Paulo Institute of Tropical Medicine (1959/2009).

(1) Instituto de Medicina Tropical de São Paulo (LIM 06). São Paulo, SP, Brasil.

(2) Faculdade de Ciências Médicas da Santa Casa de São Paulo, São Paulo, SP, Brasil

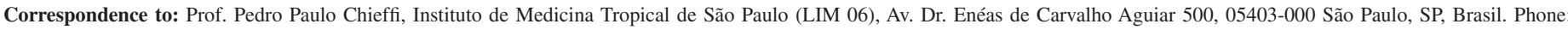
3061-7063. E-mail: pchieffi@usp.br and chiong@uol.com.br 
surveys conducted in numerous locations in Brazil showed variable prevalence rates for Toxocara canis infection in dog fecal samples, as shown in Table 1.

Frequency of human infection by Toxocara: Since the 1970s, it has been established that the essential factors for the occurrence of human infection by Toxocara and, consequently by VLM, are present in Brazil: a large number of dogs, mainly strays, infected with $T$. canis and frequent soil contamination by eggs of this ascarid ${ }^{24,25,44}$. However, only one decade later, reports on Toxocara human infection began to appear ${ }^{28}$ and from the 1990s onward, several papers had been published reporting the presence of human infection in many Brazilian regions, with variable infection rates (Table 2 ).

Serum samples from 1,023 individuals resident in Lima (Peru) were examined for anti-Toxocara antibodies in the IMT Laboratory of Helminthology, showing a frequency rate of $7.33 \%{ }^{63}$.
Almost all the surveys on the presence of anti-Toxocara antibodies in human sera were designed as transverse studies, which only permit the evaluation of frequency and, occasionally, the prevalence of infection. However, in 2003, ANARUMA et al. ${ }^{8}$ estimated the incidence rate as $17.9 \%$ in the outskirts of Campinas, in the State of São Paulo, based on two surveys conducted in January 1999 and January 2000.

Soil contamination by Toxocara eggs: As already stated, soil contamination by Toxocara eggs is frequent in almost all Brazilian regions where soil samples have been examined. Contact with soil contaminated by Toxocara eggs is considered an important risk factor for the occurrence of human infection, as is domiciliary ownership of $\operatorname{dogs}^{29}$. In Table 3, the results of the principal surveys on soil contamination by Toxocara eggs conducted in some Brazilian locations are summarized.

Eggs of ascarids, and particularly of Toxocara, are highly resistant to environmental conditions, remaining viable and infective for long periods

Table 1

Infection rates by Toxocara canis in dog fecal samples examined in Brazilian locations

\begin{tabular}{llcc}
\hline Authors/year & Local & Samples & \% Positivity \\
\hline CHIEFFI \& MÜLLER, $1976^{24}$ & Londrina, PR & 158 & 353 \\
GENNARI et al.,1999 & São Paulo, SP & 271 & 8.5 \\
OLIVEIRA-SEQUEIRA et al., $2002^{79}$ & São Paulo, SP & 41 & 5.5 \\
MURADIAN et al., $2005^{73}$ & São Paulo, SP & 158 & 39.0 \\
BLAZIUS et al., $2005^{16}$ & Itapema, SC & 401 & 14.5 \\
TÁPARO et al., $2006^{97}$ & Araçatuba, SP & 95 & 20.7 \\
LABRUNA et al., $2006^{59}$ & Monte Negro, RO & 204 & 18.9 \\
DE VASCONCELLOS et al., $2006^{41}$ & Rio de Janeiro, RJ & 138 \\
KATAGIRI et al., $2008^{58}$ & São Paulo, SP & 8.8 \\
\hline
\end{tabular}

Table 2

Frequency of human infection by Toxocara in some Brazilian regions

\begin{tabular}{|c|c|c|c|}
\hline Authors/year & Local & Number of samples & Frequency $(\%)$ of positivity \\
\hline CHIEFFI et al., $1990^{28}$ & 5 towns in the State of São Paulo & 2,025 & 3.72 \\
\hline VIRGINIA et al., $1991^{101}$ & Pernambuco & 54 & 40.0 \\
\hline CASEIRO, $1996^{22}$ & Santos, SP & 2,056 & 24.7 \\
\hline MATOS et al., $1997^{70}$ & Campo Grande, MS & 454 & 35.5 \\
\hline MOREIRA-SILVA et al., $1998^{72}$ & Vitória, ES & 100 & 39.0 \\
\hline ANARUMA FILHO et al., $2002^{7}$ & Campinas, SP & 138 & 23.9 \\
\hline CAMPOS JR. et al., $2003^{20}$ & Brasilia, DF & 602 & 21.8 \\
\hline ALDERETE et al., $2003^{6}$ & São Paulo, SP & 399 & 38.8 \\
\hline COELHO et al., $2004^{32}$ & Sorocaba, SP & 180 & 38.3 \\
\hline AGUIAR-SANTOS et al., $2004^{2}$ & Recife, PE & 386 & 39.4 \\
\hline COELHO et al., $2005^{33}$ & Guararapes, PE & 215 & 12.1 \\
\hline TEIXEIRA et al., $2006^{99}$ & Uberlândia, MG & 242 & 8.7 \\
\hline FERREIRA et al., $2007^{45}$ & State of Acre & 606 & 21.5 \\
\hline ELEFANT et al., $2008^{43}$ & State of Acre & 403 & 26.8 \\
\hline PRESTES-CARNEIRO et al., $2008^{83}$ & Teodoro Sampaio, SP & 79 & 21.5 \\
\hline SANTOS et al., $2009^{91}$ & Goiânia, GO & 1,131 & 18.9 \\
\hline
\end{tabular}


Table 3

Soil contamination by Toxocara eggs in public places in several Brazilian locations

\begin{tabular}{|c|c|c|}
\hline Authors/year & Local & $\begin{array}{c}\text { Frequency }(\%) \\
\text { of positivity }\end{array}$ \\
\hline CHIEFFI \& MÜLLER, $, 24,25$ & Londrina, $\mathrm{PR}$ & 60.0 \\
\hline FERREIRA et al., $1976^{44}$ & Rio de Janeiro, RJ & 41.6 \\
\hline CAMPOS et al., $1987^{19}$ & Goiânia, GO & 66.6 \\
\hline ALCÂNTARA et al., $1989^{5}$ & Salvador, BA & 24.8 \\
\hline COSTA-CRUZ et al., $1994^{38}$ & Uberlândia, MG & 23.1 \\
\hline SANTARÉM et al., $1998^{90}$ & Botucatu, SP & 17.5 \\
\hline COELHO et al., $2001^{31}$ & Sorocaba, SP & 53.3 \\
\hline $\begin{array}{l}\text { ANARUMA FILHO et al., } \\
2002^{7}\end{array}$ & Campinas, SP & 14.0 \\
\hline GUIMARÃES et al., $2005^{55}$ & Lavras, MG & 69.6 \\
\hline SANTARÉM et al., $2008^{89}$ & $\begin{array}{l}\text { Pontal do } \\
\text { Paranapanema, SP }\end{array}$ & 29.0 \\
\hline
\end{tabular}

in the soil. Under experimental conditions LESCANO et al.$^{63}$ reported the retention of infectivity of at least 11 months for Toxocara canis eggs maintained at $28{ }^{\circ} \mathrm{C}$ in a $2 \%$ formalin solution. In addition, CHUNG et al. ${ }^{30}$ observed a greater survival rate when the eggs were maintained at $4{ }^{\circ} \mathrm{C}$. However, certain environmental factors can influence the evolution of Toxocara eggs in the soil ${ }^{48,54}$. Under experimental conditions, QUEIROZ et al. ${ }^{85}$ concluded that low temperatures, lack of luminosity and low levels of humidity are deleterious to the development of Toxocara canis eggs.

There are some reports indicating better evolution rates for ascarid and especially for Toxocara eggs in clayey soils rather than in sandy type soils ${ }^{14}$. However, in sandy soils experimentally contaminated with Toxocara canis eggs, CHIEFFI et al. ${ }^{27}$ observed greater facility in the recovery of eggs compared to clayey soils.

Evaluating the presence and viability of Toxocara eggs in soil samples, examined monthly in Londrina (Paraná State) over a one year period, CHIEFFI \& MÜLLER ${ }^{24}$ observed the occurrence of eggs in almost all samples; however, only in the periods between May-June and September-December was the observation of viable eggs frequent. QUEIROZ et al. ${ }^{86}$ also observed two peaks of higher frequency of soil contamination by Toxocara canis eggs (February-May 2004 and AprilJuly 2005) in an 18-month survey conducted in the southern region of the municipality of São Paulo (State of São Paulo), during the period comprising February 2004 to July 2005. Research conducted in other countries also showed periods of higher soil contamination by Toxocara eggs during the year ${ }^{88,93}$.

Experimental toxocariasis in the murine model: The mouse is an excellent laboratory host to study experimental infection by T. canis in animals, because it tolerates heavy infections for long periods without suffering notable alterations and the larvae follow the enteric-pulmonarysomatic cycle with signs and symptoms similar to those produced in humans. This rodent can be also infected with other parasites, permitting the study of concomitant infections ${ }^{75}$.

In the mouse, the migratory route includes two phases: a visceral phase, during the first week, reaching the liver and lungs, with maximum peaks on postinfection days (PIDs) 2 and 3 in order to disseminate throughout all the body cavities and enter the second, myotropicneurotropic phase that occurs approximately on PID 7, within muscle and brain tissues ${ }^{1}$. LESCANO et al. ${ }^{65}$ confirmed similar results in Rattus norvegicus.

Data regarding the larval migration of $T$. canis in the mouse depend on the experimental conditions, which are often different concerning several important factors: inoculum size, larval recovery method, parasite strain and mouse strain used ${ }^{53}$.

Research in Brazil: CHIEFFI et al. ${ }^{26}$ studied the persistence of anti-Toxocara antibodies for one year in three schedules of T. canisinfected BALB/c mice, simulating a very common situation, that of the frequent occurrence of reinfection in natural conditions. In this assay, they demonstrated the persistence of antibodies against Toxocara at high levels at least six months after the experimental infection of mice with low doses of embryonated eggs from this ascarid, when the infection was obtained by either single administration of 200 T. canis eggs or three doses of 50 eggs administered on days 1, 5 and 8 . Thirty days after the first dose of infective eggs, the mice were already showing high serum levels anti-Toxocara antibodies and the highest antibody levels were determined on PID 50.

The murine model of $T$. canis has also been used to understand the role of cytokines in the infection, as reported by PECINALI et al. ${ }^{81}$. In their work, they investigated the kinetics of tissue distribution of L2 larvae in various organs and also analyzed blood and bronchoalveolar fluid (BAL) for levels of IL-6, IFN- $\gamma$, eotaxin and Regulated on Activation Normal T Cell Expressed and Secreted (RANTES) in the infected rodents. The researchers observed that liver, lung and kidney lesions correlated with larval migration as early as the first day of infection. After PID 7, larvae could also be detected in brain, skeletal muscle and heart tissues, indicating a biphasic migration pattern. Plasma and BAL of infected mice revealed increased inflammatory activity and an intense eosinophil migration was associated with increased levels of all the cytokines studied; thus, establishing a strong correlation between tissue lesions caused by the larval migration and increased plasma levels of proinflammatory cytokines as well as eosinophil chemotactic cytokines. They also described eotaxin and RANTES as potential factors responsible for the increased eosinophilic response that is characteristic of this infection.

In order to study eosinophil migration in mice after infection with $T$. canis, ANIBAL et al. ${ }^{9}$ treated mice with the leukotriene inhibitor MK886 $(1 \mathrm{mg} / \mathrm{kg} /$ day). Eosinophils in peripheral blood (PB), peritoneal cavity (PC) and bronchoalveolar lavage fluid (BAL) samples were counted between PIDs 3 and 36. Observation verified that $T$. canis infection induced systemic eosinophilia from PID 3, peaking on PIDs 6, 12 and 24 for PB, PC and BAL samples, respectively. More pronounced eosinophilia was observed in PB and PC samples than in BAL samples and MK886 downregulated eosinophilia in varying degrees in the different samples types. This data demonstrated that although systemic eosinophilia is triggered by $T$. canis infection, the inflammatory responses vary in each compartment.

RAYES et al.$^{87}$ studied the relation between tropical pyomyositis and toxocariasis in Swiss mice that where infected with T. canis embryonated 
eggs and Staphylococcus aureus, or with $S$. aureus alone, and examined for the presence of muscle abscesses. In this experimental study, muscle abscesses were more frequently observed in mice coinfected with $T$. canis and $S$. aureus. These results showed an association between toxocariasis and pyogenic abscesses of the skeletal muscle, suggesting that infection with this nematode is a cofactor in the development of tropical pyomyositis.

An assay to understand the immune response to T. canis pneumonia in mice with preweaning nutritional deprivation was conducted by MOREIRA \& ROCHA $^{71}$. The researchers worked with undernourished Swiss mice and paired controls that were infected with $T$. canis larvae at 21 days of age. Liver retinol, retinyl palmitate and inflammatory infiltrate in the lungs were compared in both groups. Significantly lower levels of retinol and retinyl palmitate in liver tissue confirmed A hypovitaminosis in the nutritionally deprived mice. Histological analysis showed similar eosinophilic infiltration in both groups at day 3 , but was significantly more severe in undernourished mice at PID 20. These findings indicated that preweaning undernourishment is associated with more severe inflammation in response to T. canis pneumonia and suggested that vitamin A deficiency that persists after nutritional rehabilitation, may contribute to the severity of $T$. canis infection. In summary, this work provided a model to observe how comorbidity of preweaning undernourishment and T. canis infection results in more severe lung inflammation.

FRANTZ et al ${ }^{47}$ studied the coinfection T. canis and Mycobacterium tuberculosis in BALB/c mice. In coinfected mice, the BAL showed enhanced eosinophil levels with diminished neutrophil and mononuclear cell accumulation. However, coinfected mice had similar mycobacterial proliferation in their lungs accompanied by identical histopathological changes and similar cytokine/nitric oxide production compared with Mycobacterium-only infected mice, suggesting that $T$. canis infection does not necessarily lead to increased susceptibility to pulmonary tuberculosis.

Some assays were conducted on experimental murine toxocariasis and chemotherapy developed here, in Brazil: LESCANO et al. ${ }^{62}$ studied the effects of administration of either cyclosporine A or betamethasone 15 days before or 45 days after experimental infection with $T$. canis on BALB/c mice. The parameters observed were: production of IgG anti-Toxocara antibodies and larval recovery at PID 90. A significant delay in the production of anti-Toxocara $\operatorname{IgG}$ antibodies was observed in all mice treated with cyclosporine A or betamethasone 15 days before infection. On the other hand, mice treated with cyclosporine A 15 days before infection, but not with betamethasone, showed a significantly higher number of trapped larvae of this ascarid in the tissues examined, indicating that the anthelmintic effect of cyclosporine A does not surpass the immunosuppressive effects when this drug is administered prior to infection with $T$. canis, while also suggesting that the use of both drugs would not significantly interfere in the immunodiagnosis of visceral larva migrans in humans.

LESCANO et al.$^{61}$ studied the effects of treatment with ivermectin, mebendazole or thiabendazole on larval recovery of T. canis and on immune response in experimental infected BALB/c mice. At the end of the experiments, a significant decrease in larvae recovered from treated mice was observed compared to infected and untreated mice with no parasitological cure; confirming that the three drugs used in this experiment had similar efficacies.
Experiments in Rattus norvegicus, Wistar strain, have also been conducted: for the first time, LESCANO et al. ${ }^{65}$ recorded the recovery of $T$. canis larvae from tissues and organs of this rat up to PID 60. They concluded that the recovery of live larvae of the parasite from different tissues of the rat indicated that this rodent possesses the conditions to act as paratenic host of $T$. canis and may transfer these larvae to carnivorous animals due to the prey-predator relationship, serving as an important factor in the circulation and maintenance of toxocariasis in nature.

SANTOS et al. ${ }^{92}$ performed the larval recovery of Toxocara cati in experimentally infected $R$. norvegicus and observed some differences in the migration of this ascarid compared with studies involving T. canis $^{65}$ : larval migration to the brain was less expressive in the case of $T$. cati and $R$. norvegicus does not appear to be a good model for ocular larva migrans compared with other rodent species ${ }^{4}$. However, this work reinforced the thesis that $R$. norvegicus is a potential reservoir for Toxocara spp. in the environment.

This year, CHIEFFI et al. ${ }^{23}$ investigated the effect of muscular migration of T. canis larvae on the muscular strength of infected $R$. norvegicus. The results obtained in this assay reinforced the hypothesis that infection by T. canis induces a decrease in muscular force and, thus, facilitates ascarid transmission via the prey-predator relationship.

Clinical features and laboratorial diagnosis of human toxocariasis: The principal clinical syndromes of human toxocariasis (visceral larva migrans and ocular larva migrans) were described more than 50 years ago. In the first case, fever, respiratory alterations, abdominal pain, hepatomegaly and eosinophilia are the main signs and symptoms determined in symptomatic patients. In patients with ocular larva migrans, visual impairment is usually unilateral and the principal causes of visual loss are fibrous traction bands, endophthalmitis, macular lesions and pars planitis ${ }^{50}$.

More recently, unusual forms of the disease had been described and denominated "covert toxocariasis", whose main features are abdominal pain, headache, coughing and hepatomegaly. Despite the high antiToxocara antibody titers determined in these patients the level of blood eosinophils is sometimes not very high ${ }^{12,98}$.

While studying 40 children with high eosinophilia and the presence of serum anti-Toxocara antibodies in São Paulo, JACOB ${ }^{56}$ verified that 26 presented clinical manifestations of visceral larva migrans. The following symptoms and signs were observed in these patients: pulmonary manifestations $(50 \%)$, fever $(15.4 \%)$, joint manifestations (7.7\%) and other alterations (22.8\%).

Clinical diagnosis: The presumptive diagnosis of VLM or OLM is generally based on clinical signs, laboratory findings and a history of geophagia and contact with dogs. The clinical signs of toxocariasis are not specific and differential diagnosis includes other parasitic diseases characterized by hypereosinophilia, such as allergic reactions, asthma, eosinophilia, leukemia, as well as other helminthiasis, such as filariasis or acute schistosomiasis. Peripheral sanguineous eosinophilia has been constantly associated with VLM. In contrast, in patients with OLM, this laboratorial finding is frequently absent ${ }^{52}$, probably due to low larva numbers. In some patients with "covert toxocariasis", eosinophilia may be absent. Promising results have been achieved in certain cases with the 
use of image techniques at the location of granulomatous lesions caused by larvae of Toxocara ${ }^{11}$.

Anatomopathological diagnosis: A definitive diagnosis of toxocariasis is possible using histopathological examination and morphological and morphometric identification of second stage larvae in tissue samples or by PCR for the detection of parasitic DNA in the tissue. However, the difficulty of obtaining biopsy material, much less material containing larvae, frustrates this type of diagnosis ${ }^{68,94}$. The use of immunohistochemical techniques in the analysis of liver biopsy ${ }^{17}$ can permit larval antigen location in the histological sections examined. Such difficulties in the identification of Toxocara larvae stimulated the development of diagnostic immunological techniques that have become commonly used in the laboratory routine.

Immunodiagnosis: In most cases, laboratorial diagnosis depends on the demonstration of specific anti-Toxocara antibodies in the serum or ocular fluid of patients suspected of infection. Different immunological tests have been described: intradermal reactivity, complement fixation, bentonite flocculation, indirect hemagglutination, immunodiffusion, larvae immunoprecipitation, direct or indirect immunofluorescence, immunoenzymatic test (ELISA) and radioimmunoassay ${ }^{57}$. The most commonly used antigens in these tests are somatic extracts of adult worms or larvae, sections of worms or larvae and metabolic products of larvae maintained in culture. Due to differences in these antigenic preparations, the tests show wide variations in sensitivity and specificity.

ELISA: The introduction of Immunoenzymatic assay (ELISA), based on the use of antigen extracted from larval culture of T. canis (antigen TES), resulted in a test with good specificity and sensitivity ${ }^{21,40,51}$. However, the evaluation of the true sensitivity and specificity of serological tests for toxocariasis in human populations is not possible due to lack of parasitological methods to diagnose the disease in a definitive form. Prior to the use of TES as a diagnostic antigen, much of the research on human Toxocara infection had been based on tests that used somatic hydrosoluble antigens derived from embryonated eggs, larvae or adults. Many of these antigens lacked sensitivity and expressed high degrees of cross reactivity with Ascaris and other geo-helminthes, such as $S$. stercoralis ancylostomids and T. trichiura ${ }^{95}$. Although the use of TES antigen has notably improved the efficiency of the test, this may not be specific enough when used in countries where this type of infection is prevalent ${ }^{66,86}$. Therefore, commercial "kits" that can not determine previous absorption of sera with antigens of these parasites can be of limited use in the diagnosis of toxocariasis in tropical countries.

In 1984, BACH-RIZZATI ${ }^{10}$ standardized the ELISA test for the detection of anti-Toxocara antibodies in Brazil, achieving similar results to both somatic and TES larva antigens. The author considered that after the absorption of the serum with Ascaris suum antigens, titers above 1:64 were related to possible cases of toxocariasis in humans. CAMARGO et al. ${ }^{18}$ standardized the DOT-ELISA technique for the diagnosis of toxocariasis in Brazil and when they compared this technique with the ELISA test, they concluded that the DOT-ELISA presented advantages in relation to stability, the short duration of execution and lower cost. In 2006, ELEFANT et al. ${ }^{42}$ standardized the ELISA IgG, IgA and IgE tests after using TES in the serological follow-up of patients with toxocariasis after chemotherapy in São Paulo.
Immunoblotting: The study of the T. canis antigen by applying the techniques of SDS-PAGE and "Western blotting" (WB), conducted by AKAO et $a l .^{3}$, revealed eight different bands with molecular weights varying from 32 to $140 \mathrm{kDa}$ and they observed differences between the acute and chronic phases of the infection, with the appearance of bands of low molecular weight after 26 weeks of infection. MAGNAVAL et $a l .{ }^{67}$ used the WB technique to confirm positivity determined in human sera previously processed by the ELISA technique for IgG antibodies using antigen TES and achieved greater specificity with fractions of low molecular weight (24 to $35 \mathrm{kDa}$ ). The study by NUNES et $a .^{78}$, using the Immunoblot test, determined that the 55-66 kDa antigenic complex was responsible for the cross reactivity between $T$. canis and A. suum; whereas $\mathrm{LYNCH}$ et al. ${ }^{66}$ had stated that strong cross reactivity between these two ascarids occurred in the $81 \mathrm{kDa}$ antigen. In Brazil, $\mathrm{JACOB}^{56}$ conducted a sequential study of patients with VLM and after treatment, WB showed the disappearance of certain fractions of high molecular weight (97-116 and 200-210 kDa), a pattern that could represent the individual behavior of the immune response of the patient and may be related to the slow fall in titers observed in the ELISA.

Recombinant antigen: Limitations due to cross reactivity of the TES antigen with other helminth antigens and the difficulties in producing sufficient quantities of a standardized antigen has lead researchers to prepare a recombinant TES antigen for use in serodiagnosis. The recombinant antigens can provide a basis for serological tests with greater sensitivity and specificity compared with tests that use native TES. Two proteins of the recombinant TES have potential value in the serological diagnosis of human toxocariasis: the first, TES-30, is a recombinant protein of the second stage larva corresponding to the $30 \mathrm{kDa}$ TES antigen. When used as an antigen in WB, this protein reacts specifically with sera of patients with toxocariasis, but not with sera of patients with Brugia malayi, dirofilariasis or ascariasis. Cross reactions with sera of infections with Anisakis have been observed, however, these were eliminated when the sera were previously absorbed with Anisakis antigen ${ }^{102}$. The second recombinant protein is the expression of the Tc-muc- 1 gene that codifies the TES-120, which reacts with the sera of individuals with toxocariasis, but not with sera of patients with other helminthiasis or with protozoan infections ${ }^{46}$. COELHO et al..$^{34}$ developed an ELISA test in Brazil using this immobilized recombinant antigen in solid phase consisting of pearls of polysiloxane/polyvinyl alcohol. Compared with the conventional test, this test presented a greater difference in density optics between the positive and negative results and the advantages of lower cost and greater facility in achieving the solid phase. The same group evaluated the prevalence of toxocariasis in North-eastern Brazil using the ELISA technique with the recombinant antigen ${ }^{33}$.

Ocular toxocariasis: Serological diagnosis of OLM using the TESELISA IgG is more challenging than serodiagnosis of VLM or "covert toxocariasis", because the levels of antibodies in the serum are usually low or undetectable ${ }^{51}$ and eosinophilia is often absent. When OLM is suspected, aqueous or vitreous fluids are the best options for diagnostic samples. POLLARD et al. ${ }^{82}$ recommended that the ocular fluids must be diluted at a ratio of 1:8 before being tested, in comparison with a dilution of 1:32 for sera in suspected VLM cases, precisely because approximately $10 \%$ of patients with clinical signs of OLM presented negative results in the ELISA test. 
Neurotoxocariasis: Neurological syndromes observed during infection of the central nervous system (CNS) with Toxocara are generally unspecific and frequently, eosinophilia is a nonexistent sign. Imagenology in medicine is especially useful to study these patients. Magnetic resonance can detect granulomas located in the cortical or subcortical layers and these can appear as foci of high intensity protons. When associated with eosinophilia in the cerebrospinal fluid (CSF), such images are consistent with infection by Toxocara. Observation of larvae of the ascarid in the CSF, in brain tissue or meninges and/or a positive titer for anti-Toxocara antibodies in this fluid represents a decisive diagnosis ${ }^{72}$. In Espirito Santo, Brazil, MUSSO et al..$^{74}$ examined CSF of children using ELISA IgG anti-Toxocara in order to determine whether any association existed between Toxocara and viral or bacterial infection in the CNS of the same and concluded that infection with this parasite is not associated with viral or bacterial meningitis or meningoencephalitis. Previously, COSTA-BARRA et al. ${ }^{36}$ had reported a case of VLM with a mixed form of clinical presentation combining neurological features associated with multiple joint aches and pulmonary alterations, which, after treatment with thiabendazole, evolved to complete clinical and laboratorial remission.

\section{RESUMO}

\section{Toxocaríase humana: contribuição dos pesquisadores brasileiros}

São abordados os principais aspectos da história natural da infecção humana por larvas de Toxocara que pode resultar na ocorrência da síndrome de larva migrans visceral e/ou ocular. Deu-se destaque, principalmente, à contribuição de pesquisadores brasileiros e, em especial, aos pertencentes ao quadro do Instituto de Medicina Tropical de São Paulo.

\section{REFERENCES}

1. ABO-SHEHADA, M.N. \& HERBERT, I.V. - The migration of larval Toxocara canis in Mice. II. Post-intestinal migration in primary infections. Vet. Parasit., 17: 75-83, 1984

2. AGUIAR-SANTOS, A.M; ANDRADE, L.D; MEDEIROS, Z. et. al. - Human toxocariasis: frequency of anti-Toxocara antibodies in children and adolescents from an outpatient clinic for lymphatic filariasis in Recife, Northeast Brazil. Rev. Inst. Med. trop. S. Paulo, 46: 81-85, 2004.

3. AKAO, N.; KONDO, K.; OKAMOTO, T. \& YOSHIMURA, H. - Antigenic analysis of excretory products of $2^{\text {nd }}$.stage larvae of Toxocara canis and the antigen recognition in the course of infection. Jap. J. Parasit., 32: 551-558, 1983.

4. ALBA-HURTAdO, F.; MUÑOZ-GUZMÁN, M.A.; VALDIVIA-ANDA, G.; TÓRTORA, J.L. \& ORTEGA-PIERRES, M.G. - Toxocara canis: larval migration dynamics, detection of antibody reactivity to larval excretory-secretory antigens and clinical findings during experimental infection of gerbils (Meriones unguiculatus). Exp. Parasit., 122: 1-5, 2009

5. ALCÂNTARA, N.; BAVIA, E.; SILVÃO, R.M. \& CARVALHO, E. - Environmental contamination by Toxocara sp eggs in public areas of Salvador, Bahia State, Brazil. Rev. Soc. bras. Med. trop., 22: 187-190, 1989.

6. ALDERETE, J.M.; JACOB, C.M.; PASTORINO, A.C. et al. - Prevalence of Toxocara infection in schoolchildren from the Butantã region, São Paulo, Brazil. Mem. Inst. Oswaldo Cruz, 98: 593-597, 2003.

7. ANARUMA FILHO, F.; CHIEFFI, P.P.; CORREA, C.R. et al. - Human toxocariasis: a seroepidemiological survey in the municipality of Campinas (SP), Brazil. Rev. Inst. Med. trop. S. Paulo, 44: 303-307, 2002.

8. ANARUMA FILHO, F.; CHIEFFI, P.P.; CORREA, C.R. et al. -Human toxocariasis: incidence among residents in the outskirts of Campinas, State of São Paulo, Brazil. Rev. Inst. Med. trop. S. Paulo, 45: 293-294, 2003.
9. ANIBAL, F.F.; ROGERIO, A.P.; MALHEIRO, A.; MACHADO, E.R. \& MARTINSFILHO, O.A. - Impact of MK886 on eosinophil counts and phenotypic features in Toxocariasis. Scand. J. Immunol., 65: 344-352, 2007.

10. BACH-RIZZATTI, B.C. - Desenvolvimento do teste imunoenzimático ELISA para o diagnóstico da toxocaríase humana. São Paulo, 1984. (Dissertação de Mestrado - Faculdade de Ciências Farmacêuticas da Universidade de São Paulo).

11. BALDISSEROTTO, M.; CONCHIN C.F.; SOARES M.D.A.G.; ARAUJO M.A. \& KRAMER, B. - Ultrasound findings in children with toxocariasis: report on 18 cases. Pediat. Radiol., 29: 316-319, 1999.

12. BASS, J.L.; MEHTA, K.A.; GLICKMAN, L.T. \& EPPES, B.M. - Clinically inapparent Toxocara infection in children. New Engl. J. Med., 308: 723-724, 1983.

13. BEAVER. P. - Larva migrans: a review. Exp. Parasit., 5: 587-621, 1956.

14. BEAVER, P.C. - Biology of soil-transmitted helminths: the massive infection. Hith Lab. Sci., 12: 116-125, 1975.

15. BEAVER, P.C., SNYDER, H.; CARRERA, G; DENT, J. \& LAFFERTY, J. - Chronic eosinophilia due to visceral larva migrans. Pediatrics, 9: 7-19, 1952.

16. BLAZIUS, R.D.; EMERICK, S.; PROPHIRO, J.S.; ROMÃO, P.R.T. \& SILVA, O. S. Ocorrência de protozoários e helmintos em amostras de fezes de cães errantes da cidade de Itapema, Santa Catarina. Rev. Soc. bras. Med. trop., 38: 73-74, 2005.

17. BRITO, T.; CHIEFFI, P.P.; PERES, B.A. et al. - Immunohistochemical detection of toxocaral antigens in human liver biopsies. Int. J. surg. Path., 2: 117-124, 1994.

18. CAMARGO, E.D.; NAKAMURA, P.M.; VAZ, A.J. et al - Standardization of DOTELISA for the serological diagnosis of Toxocariasis and comparison of the assay with ELISA. Rev. Inst. Med. trop. S. Paulo, 34: 55-60, 1992.

19. CAMPOS, D.M.B.; LEÃO, D.A.; ISAC, E. \& CALIL, F. - Pesquisa de ovos de Toxocara sp em localidades públicas da cidade de Goiânia, Goiás.1 Comparação de métodos de exame. Rev. Pat. trop., 16: 7-11, 1987.

20. CAMPOS JÚNIOR, D.; ELEFANT, G.R.; DE MELO E SILVA, E.O. et al. - Frequency of seropositivity to Toxocara canis in children of different socioeconomic strata. Rev. Soc. bras. Med. trop., 36: 509-513, 2003.

21. CARLIER, Y.; YANG, J.; BOUT, D. \& CAPRON, A. - The use of an excretory-secretory antigen for an ELISA specific sero-diagnosis of visceral larva migrans. Biomed. Pharmacother., 36: 39-42, 1982.

22. CASEIRO, M.M. - Sindrome de Larva Migrans visceral causada por larvas de Toxocara canis (Werner, 1782 e Stiles, 1905), no município de Santos, São Paulo, 1994-1996. São Paulo, 1996. (Dissertação de Mestrado - Faculdade de Medicina da Universidade de São Paulo).

23. CHIEFFI, P.P.; AQUINO, R.T; PASCHOALOTTI, M.A.; RIBEIRO, M.C.S. \& NASELLO, A.G. - Muscular strength decrease in Rattus norvegicus experimentally infected by Toxocara canis. Rev. Inst. Med. trop. S. Paulo, 51: 73-75, 2009.

24. CHIEFFI, P.P. \& MULLER, E.E. - Prevalência de parasitismo por Toxocara canis em cães e a presença de ovos de Toxocara sp. no solo de localidades públicas de zona urbana do município de Londrina, Estado do Paraná. Rev. Saúde públ. (S. Paulo), 10: $367-372,1976$

25. CHIEFFI, P.P. \& MÜLLER, E.E. - Estudo da variação mensal na contaminação do solo por ovos de Toxocara sp. (Nematoda, Ascaroidea), na zona urbana do Município de Londrina, Estado de Paraná, Brasil. Rev. Inst. Adolfo Lutz, 38: 13-16, 1978.

26. CHIEFFI, P.P.; PERES, B.A.; MELLO, E.O.; KANAMURA, H. \& BRANDÃO, M.M. Persistence of specific antibody response in different experimental infections of mice with Toxocara canis larvae. Rev. Inst. Med. trop. S. Paulo, 37: 187-190, 1995.

27. CHIEFFI, P.P.; QUEIROZ, M.L; MEHLMANN, F.; PASCHOALOTTI, M.A. \& LESCANO, S.A. - Recovering of Toxocara canis eggs from samples of experimentally contaminated soil. Rev. Inst. Med. trop. S. Paulo, 50: 361-362, 2008 . 
28. CHIEFFI, P.P.; UEDA, M.; CAMARGO, E.D. et al. - Visceral larva migrans: a seroepidemiological survey in five municipalities of São Paulo State, Brazil. Rev. Inst. Med. trop. S. Paulo, 32: 204-210, 1990.

29. CHIEFFI, P.P.; UEDA, M.; CAMARGO, E.D. et al. - Contacto domiciliar e profissiona com cães como fatores de risco para infecção humana por larvas de Toxocara. Rev. Inst. Med. trop. S. Paulo, 30: 379-382, 1988.

30. CHUNG, L.Y.; FANG, B.H.; CHANG, J.H.; CHYE, S.M. \& YEN, C.M. - The infectivity and antigenicity of Toxocara canis eggs can be retained after long-term preservation. Ann. trop. Med. Parasit., 98: 251-260, 2004.

31. COELHO, L.M.P.S; DINI, C.Y.; MILMAN, M.H.S.A. \& OLIVEIRA, S.M. - Toxocara spp eggs in public squares of Sorocaba, São Paulo State, Brazil. Rev. Inst. Med. trop. S. Paulo, 43: 189-191, 2001.

32. COELHO, L.M.; SILVA, M.V.; DINI, C.Y. et al. - Human toxocariasis: a seroepidemiological survey in schoolchildren of Sorocaba, Brazil. Mem. Inst. Oswaldo Cruz, 99: 553-557, 2004.

33. COELHO, R.A.L.; CARVALHO Jr., L.B.; PEREZ, E.P. et al. - Prevalence of toxocariasis in Northeastern Brazil based on serology using recombinant Toxocara canis antigen. Amer. J. trop. Med. Hyg., 72: 103-107, 2005.

34. COÊLHO, R.A.; YAMASAKI, H.; PEREZ, E. \& DE CARVALHO Jr., L.B. - The use of polysiloxane/polyvinyl alcohol beads as solid phase in IgG anti-Toxocara canis detection using a recombinant antigen. Mem. Inst. Oswaldo Cruz, 98: 391-393, 2003.

35. CÔRTES, V.A.; PAIM, G.V. \& ALENCAR-FILHO, R.A. - Infestação por ancilostomídeos e toxocarídeos em cães e gatos apreendidos em vias públicas, São Paulo (Brasil). Rev. Saúde públ. (S. Paulo), 22: 341-343, 1988.

36. COSTA BARRA, L.A.; FERREIRA DOS SANTOS, W.; CHIEFFI, P.P. et al. - Larva Migrans visceral: forma mista de apresentação em adulto. Aspectos clínicos e laboratoriais. Rev. Soc. bras. Med. trop., 29: 373-376, 1996.

37. COSTA, J.O.; GUIMARÃES, M.P.; LIMA, W.S. \& LIMA, E.A.M. - Freqüência de endo e ectoparasitos de cães capturados nas ruas de Vitória, ES, Brasil. Arq. bras. Med. vet. Zoot., 42: 451-452, 1990.

38. COSTA-CRUZ, J.M.; NUNES, R.S. \& BUSO A.G. - Presence of Toxocara spp eggs in public squares of Uberlandia city, Minas Gerais, Brazil. Rev. Inst. Med. trop. S. Paulo, 36: 39-42. 1994.

39. DE OLIVEIRA, D.; DA SILVA, P.; PARREIRA, V; RIBEIRO, S. \& GOMES, J. Prevalência de endoparasitos em cães da região de Uberlândia, MG. Brasil. Braz. J. Vet. Res. anim. Sci., 27: 193-197, 1990.

40. DE SAVIGNY, D.H.; VOLLER, A. \& WOODRUFF, A.W. - Toxocariasis: serological diagnosis by Enzyme Immuno Assay. J. clin. Path., 32: 284-288, 1979.

41. DE VASCONCELlOS, M.C.; DE BARROS, J.S. \& DE OLIVEIRA, C.S. - Intestinal parasitic helminths in institutionalized dogs of Rio de Janeiro. Rev. Saude públ., 40: $321-323,2006$

42. ELEFANT, G.R.; HOSHINO-SHIMIZU, S.; SANCHEZ, M.C.A.; JACOB, C.M.A \& FERREIRA, A.W. - A serological follow-up of toxocariasis patients after chemotherapy based on the detection of IgG, IgA, and IgE antibodies by enzymelinked immunosorbent assay. J. clin. Lab. Anim., 20: 164-172, 2006.

43. ELEFANT, G.R.; SILVA-NUNES, M.; MALAFRONTE, R.S.; MUNIZ, P.T. \& FERREIRA, M.U. - Human toxocariasis in rural Brazilian Amazonia: seroprevalence, risk factors, and spatial distribution.. Amer. J. trop. Med. Hyg., 79: $93-98,2008$

44. FERREIRA, L.F.; OLIVEIRA, E.L. \& CAMILO-COURA, L. - Sobre a presença de ovos de Toxocara em praças da cidade do Rio de Janeiro. Rev. Soc. bras. Med. trop. 10: 51-54, 1976.

45. FERREIRA, M.U.; RUBINSKY-ELEFANT, G.; DE CASTRO T.G. et al. - Bottle feeding and exposure to Toxocara as risk factors for wheezing illness among under-five Amazonian children: a population-based cross-sectional study. J. trop. Pediat., 53: 119-124. 2007.
46. FONG, M.Y; LAU, Y.L.; INIT, I. et al. - Recombinant expression of Toxocara canis excretory-secretory antigens TES-120 in Escherichia coli. Southeast Asian J. trop. Med. publ. Hlth, 34: 723-726, 2003

47. FRANTZ, F.G.; ROSADA, R.S.; TURATO, W.M. et al. - The immune response to Toxocariasis does not modify susceptibility to Mycobacterium tuberculosis infection in BALB/c mice. Amer. J. trop. Med. Hyg., 77: 691-698, 2007.

48. GAMBOA, M.I. - Effects of temperature and humidity on the development of eggs of Toxocara canis under laboratory conditions.J. Helminthol., 79: 327-331, 2005.

49. GENNARI, S.M.; KASAI, N.; PENA, H.F.J. \& CORTEZ, A. - Ocorrência de protozoários e helmintos em amostras de fezes de cães e gatos da cidade de São Paulo. Braz. J. Vet. Res. An. Sci., 36: 87-91, 1999.

50. GILLESPIE, S.H. - The clinical spectrum of human toxocariasis. In: LEWIS, J.W. \& MAIZELS, R.M., ed. Toxocara and toxocariasis. Clinical, epidemiological and molecular perspectives. London, Institute of Biology and the British Society for Parasitology, 1993. p. 55-61.

51. GLICKMAN, L.T.; GRIEVE, R.; LAURIA, S. \& JONES, D. - Serodiagnosis of ocular toxocariasis, a comparison of two antigens. J. clin. Path., 38: 103-107, 1985.

52. GLICKMAN, L.T. \& SCHANTZ, P.M. - Epidemiology and pathogenesis of zoonotic toxocariasis. Epidemiol. Rev., 3: 230-250, 1981.

53. GUILlen, J.; BARDON, R.; DOMINGUEZ, P. \& DEL HOYO, C. - Migración larvaria de Toxocara canis y respuesta eosinofílica en las cepas murinas BALB/c y C57BL/10. Rev. ibér. Parasit., 50: 289-299, 1990.

54. GUILLEN-LLERA, J.L.; CUELLAR DEL HOYO, C. \& AGUILA DE LA PUENTE C. - Fotodependencia del desarrollo embrionário de Toxocara canis (Werner, 1782) Stiles, 1905. Rev. ibér. Parasit., 46: 67-74,1986.

55. GUIMARÃES, A.M.; ALVES, E.G.L.; REZENDE, G.F. \& RODRIGUES, M.C. - Ovos de Toxocara sp. e larvas de Ancylostoma sp. em praça pública de Lavras, MG. Rev. Saúde públ. (S. Paulo), 39: 293-295, 2005.

56. JACOB, C.M.A. - Análise evolutiva dos parâmetros clínico-laboratoriais da toxocaríase visceral na infância. São Paulo, 1995. (Tese de Doutoramento Faculdade de Medicina da USP).

57. JACOB, C.M.A.; PERES, B.A.; CHIEFFI, P.P. et al. - Síndrome de larva migrans visceral por Toxocara canis. Pediatria (S. Paulo), 9: 9-12, 1987.

58. KATAGIRI, S. \& OLIVEIRA-SEQUEIRA, T.C.G. - Prevalence of dog intestinal parasites and risk perception of zoonotic infection by dog owners in São Paulo State, Brazil. Zoonoses publ. Hlth, 55: 406-413, 2008.

59. LABRUNA, M.B.; PENA, H.F.J.; SOUZA, S.L.P. et al. - Prevalência de endoparasitas em cães da área urbana do Município de Monte Negro, Rondônia. Arq. Inst. Biol. (S. Paulo), 3: 183-193, 2006

60. LARA, S.I.M.; TAROUCO, M.R.R. \& RIBEIRO, P.B. - Helmintos parasitos de Canis familiaris de Pelotas - Rio Grande do Sul. Arq. Esc. Vet. UFMG, 33: 293-297, 1981

61. LESCANO, S.A.Z.; CHIEFFI, P.P.; AMATO NETO, V.; IKAI, D.K. \& RIBEIRO, M.C.S. - Anti-helmínticos na toxocaríase experimental: efeito na recuperação de larvas de Toxocara canis e na resposta humoral. J. bras. Pat.. Med. Lab., 41: 21-24, 2005.

62. LESCANO, S.A.Z; CHIEFFI, P.P.; IKAI, D.K. \& RIBEIRO, M.C.S. - Efeitos da ciclosporina A e betametasona na toxocaríase murina experimental. Rev. Soc. bras. Med. trop., 37: 22-24, 2004.

63. LESCANO, S.A.; CHIEFFI, P.P.; PERES, B.A. et al. - Soil contamination and human infection by Toxocara sp. in the urban area of Lima, Peru. Mem. Inst. Oswaldo Cruz, 93: 733-734. 1998 .

64. LESCANO, S.Z.; NAKHLE, M.C. \& CHIEFFI, P.P. - Effect of "in vitro" cultivation time on the infectivity of Toxocara canis eggs. Rev. Inst. Med. trop. S. Paulo, 40: 201-202. 1998. 
65. LESCANO, S.Z.; QUEIROZ, M.L. \& CHIEFFI, P.P. - Larval recovery of Toxocara canis in organs and tissues of experimentally infected Rattus norvegicus. Mem. Inst. Oswaldo Cruz, 99: 627-628, 2004.

66. LYNCH, N.; WILKE, S.L.; HODGEN, A.N. \& TURNER, K. - Specificity of Toxocara ELISA in tropical populations. Paras. Immunol., 10: 323-337, 1988.

67. MAGNAVAL, J.F.; FABRE, P.; MAURIERS, J.; CHARLET, C. \& LARRARD, B. Application of the Western blotting procedure for the immunodiagnosis of human toxocariasis. Parasit. Res., 77: 697-702, 1991

68. MAGNAVAL, J.F.; GLICKMAN, L.T.; DORCHIES, P. \& MORASSIN, B. - Highlights of human toxocariasis. Korean J. Parasit., 39: 1-11, 2001

69. MATOS, M.S.; LEITE, M.L.A.S.; PEDREIRA, E.D.; COSTA, A.A. \& ELOY, E.E. Estudo cronológico da frequiência de ovos de helmintos gastrointestinais em fezes de cães (Canis familiaris). Pesq. Vet. bras., 1: 44-45, 1981.

70. MATOS, M.F.; MELITÃO, D.N.; BRUM, M.A. et al. - Presence of anti-Toxocara antibodies in children selected at Hospital Universitário, Campo Grande, MS, Brazil. Rev. Inst. Med. trop. S. Paulo, 39: 49-50, 1997.

71. MOREIRA, D.S. \& ROCHA, G.M. - Toxocara canis: impact of preweaning nutritional deprivation on the pathogenesis of pneumonia in the mouse. Exp. Parasit., 110: 349-352, 2005

72. MOREIRA-SILVA, S.F.; RODRIGUES, M.G.; PIMENTA, J.L. et al. - Toxocariasis of the central nervous system: with report of two cases. Rev. Soc. bras. Med. trop., 37: 169-174. 2004

73. MURADIAN, V.; GENNARI, S.M.; GLICKMAN, L.T. \& PINHEIRO, S.R. Epidemiological aspects of Visceral Larva Migrans in children living at São Remo Community, São Paulo (SP), Brazil. Vet. Parasit., 134: 93-97, 2005.

74. MUSSO, C.; LEMOS, E.M.; TSANACLIS, A.M.C. \& PEREIRA, F.E.L. - Toxocara infection is not associated with viral or bacterial central nervous system infection. Neuropediatrics, 37: 126-129, 2006.

75. NICHOLAS, W.L.; STEWART, A.C. \& MITCHELL, F. - Antibody responses to Toxocara canis using sera from parasite-infected mice and protection from toxocariasis by immunisation with ES antigens. Aust. J. exp. Biol. Med. Sci., 62: 619-626, 1984

76. NICHOLS, R.L. - The etiology of Visceral Larva Migrans. J. Parasit., 42: 349-362, 1956.

77. NOORDIN, R.; SMITH, H.V.; MOHAMAD, S.; MAIZELS, R.M. \& FONG, M.Y. Comparison of IgG-ELISA and IgG4- ELISA for Toxocara serodiagnosis. Acta trop., 93: 57-62, 2005.

78. NUNES, C.M. \& OGASSAWARA, S. - Recuperação de larvas de Toxocara canis de tecidos de camundongo. Braz. J. vet. Res. Anim. Sci. S. Paulo, 34: 41-43, 1997.

79. OLIVEIRA-SEQUEIRA, T.C.G.; AMARANTE, A.F.T.; FERRARI, T.B. \& NUNES, L.C. - Prevalence of intestinal parasites in dogs from São Paulo State, Brazil. Vet. Parasit., 103: 19-27, 2002.

80. OVERGAAUW, P.A.M. \& NEDERLAND, V. - Aspects of Toxocara epidemiology: toxocarosis in dogs and cats. Crit. Rev. Microbiol.,.23: 233-251, 1997.

81. PECINALI, N.R.; GOMES, R.N.; AMENDOEIRA, F.C. et al. - Influence of murine Toxocara canis infection on plasma and bronchoalveolar lavage fluid eosinophil numbers and its correlation with cytokine levels. Vet. Parasit., 134: 121-130, 2005.

82. POLLARD, Z.F.; JARRET, W.H.; HAGLER, W.H; ALLAIN, D.S. \& SCHANTZ, P.M. - ELISA for diagnosis of ocular toxocariasis. Ophthalmology, 86: 743-749, 1979.

83. PRESTES-CARNEIRO, L.E.; SANTAREM, V.; ZAGO, S.C. et al. - Sero-epidemiology of toxocariasis in a rural settlement in São Paulo State, Brazil. Ann. trop. Med. Parasit., 102: 347-356, 2009.

84. PROCIV, P. \& CROESE, J. - Human enteric infection with Ancylostoma caninum: hookworms reappraised in the light of a "new" zoonosis. Acta trop., 62: 23-44, 1996
85. QUEIROZ, M.L.; MEHLMANN, F.M.G.; PASCHOALOTTI, M.A.; LESCANO, S.A.Z. \& CHIEFFI, P.P. - Efeitos de variáveis ambientais na evolução de ovos de Toxocara canis em condições experimentais. Arq. Méd. Hosp. Fac. Ciênc. méd. Santa Casa S. Paulo, 54: 6-8, 2009.

86. QUEIROZ, M.L.; SIMONSEN, M.; PASCHOALOTTI, M.A. \& CHIEFFI, P.P. Frequency of soil contamination by Toxocara canis eggs in the south region of São Paulo municipality (SP, Brazil) in a 18 month period. Rev. Inst. Med. trop. S. Paulo, 48: 317-319. 2006.

87. RAYES, A.A.; NOBRE, V.; TEIXEIRA, D. et al. - Tropical pyomyositis and human toxocariasis: a clinical and experimental study. Amer. J. Med., 109: 422-425, 2000.

88. SALINAS, P.; REYES, L.; SOTOMAYOR, M.T. \& LETONIA, T. - Prevalencia de huevos de Toxocara sp. en algunas plazas públicas de la región Metropolitana de Santiago, Chile. Bol. chil. Parasit., 42: 33-36, 1987.

89. SANTARÉM, V.A.; FRANCO, E.C.; KOZUKI, F.T.; FINI, D. \& PRESTESCARNEIRO, L.E. - Environmental contamination by Toxocara spp. eggs in a rural settlement in Brazil. Rev. Inst. Med. trop. S. Paulo, 50: 279-281, 2008

90. SANTARÉM, V.A; SARTOR, I.F. \& BERGAMO, F.M. - Contamination by Toxocara spp eggs, in public parks and squares in Botucatu, São Paulo, Brazil. Rev. Soc. bras. Med. trop., 31: 529-532, 1998.

91. SANTOS, G.M.; ALMEIDA E SILVA, S.; PASSOS BARBOSA, A. \& CAMPOS, D.M.B. - Investigação soroepidemiológica sobre Larva Migrans Visceral por Toxocara canis em usuários de Serviços de Saúde de Goiania, GO. Rev. Pat. trop., 38: 197-206, 2009

92. SANTOS, S.V.; LESCANO, S.Z.; CASTRO, J.M. \& CHIEFFI, P.P. - Larval recovery of Toxocara cati in experimentally infected Rattus norvegicus and analysis of the rat as potential reservoir for this ascarid. Mem. Inst. Oswaldo Cruz, 104: 933-934, 2009.

93. SHIMIZU, T. - Prevalence of Toxocara eggs in sandpits in Tokushima city and its outskirts. J. Vet. Med. Sci., 55: 807-811, 1993.

94. SMITH, H.V. - Antibody reactivity in toxocariasis. In: LEWIS, J.W. \& MAIZELS, R.M., ed. Toxocara and toxocariasis: clinical, epidemiological and molecular perspectives. London, Institute of Biology, 1993. p. 91-109.

95. SMITH, H.V.; QUINN, R.; BRUCE, R.G. \& GIRDWOOD, R.W.A. - Antigenic relationships between certain Ascaroidea of presumed medical importance. 2. Analysis of developmental stages. Acta parasit. pol., 48: 467-476, 1983.

96. SMITH, H.; HOLLAND, C.; TAYLOR, M. et al. - How common is human toxocariasis? Towards standardizing our knowledge. Trends Parasit., 25: 182-188, 2009.

97. TÁPARO, C.V.; PERRI, S.H.; SERRANO, A.C. et al. - Comparison between coproparasitological techniques for the diagnosis of helminth eggs or protozoa oocysts in dogs. Rev. bras. Parasit. Vet., 15: 1-5, 2006.

98. TAYLOR, M.R.H.; KEANE, C.T.; O’CONNOR, P.; GIRDWOOD, R.W.A. \& SMITH, H. - Clinical features of covert toxocariasis. Scand. J. infect. Dis., 19: 696-699, 1987.

99. TEIXEIRA, C.R.; CHIEFFI, P.P.; LESCANO, S.A. et al. - Frequency and risk factors for toxocariasis in children from a pediatric outpatient center in southeastern Brazil. Rev. Inst. Med. trop. S. Paulo, 48: 251-255, 2006.

100. VASCONCELlOS, M.C.; BARROS, J.S.L. \& OLIVEIRA, C.S. - Parasitas gastrointestinais em cães institucionalizados no Rio de Janeiro, RJ. Rev. Saúde públ. (S. Paulo), 40: 321-322, 2006

101. VIRGINIA, P.; NAGAKURA, K.; FERREIRA, O. \& TATENO, S. - Serologic evidence of toxocariasis in northeast Brazil. Jap. J. med. Sci. Biol., 44: 1-6, 1991.

102. YAMASAKI, H.; ARAKI, K.; LIM, P.K.C. et al. - Development of highly specific recombinant Toxocara canis second stage larva excretory-secretory antigens for immunodiagnosis of human toxocariasis. J. clin. Microbiol., 38: 1409-1413, 2000.

Received: 13 November 2009

Accepted: 30 November 2009 